\title{
An Association Study of Cervical Cancer Correlated with The Age of Coitarche in Dr. Soetomo Hospital Surabaya
}

\author{
Dewi Sulistyawati ${ }^{1}$, Zakiyatul Faizah ${ }^{2}$, Eighty Mardiyan Kurniawati ${ }^{3}$ \\ ${ }^{1}$ Faculty of Medicine, Airlangga University, Surabaya, Indonesia \\ 2 Department of Biomedicine, Airlangga University, Surabaya, Indonesia \\ ${ }^{3}$ Department of Obstetrics and Gynecology, Airlangga University, Surabaya, Indonesia
}

\section{ARTICLE INFO}

Received : 22 April 2019

Reviewed : 27 May 2019

Accepted : 15 January 2020

Keywords:

age of coitarche, cervical cancer, early coitarche

\author{
ABSTRACT
}

Background: Cervical cancer is one of the deadliest diseases for women's lives. It is estimated that almost every hour, one died because of cervical cancer and $70 \%$ of new cases are found in an advanced stage. Many factors could cause cervical cancer, one of the risk factors is the age of the early coitarche. This study aims to determine the association between the age of coitarche and cervical cancer.

\begin{abstract}
Methods: This study was an analysis of observational study with a case-control design. There were two groups in this study; the case group of outpatients who were diagnosed with cervical cancer and the control group of outpatients who had normal cervical cytology by Papanicolaou screening. The 39 respondents of both the control and case groups, calculated using the Lemeshow's formula for consecutive sampling, were interviewed for their details concerning reproductive and sexual histories, socio-economic status, hygiene, and education. The independent variable in this study was the age of coitarche; the dependent variable was cervical cancer. The data were analyzed descriptively and using the bivariate analysis (Chi-square) with $\alpha=0.05$.
\end{abstract}

Results: It is identified that 39 respondents for each group (case and control) have almost the same percentage of the age of coitarche in One-Stop Oncology Polyclinic (POSA's outpatient); early coitarche of $43.6 \%$ and late coitarche of $56.4 \%$. The age of early coitarche in Obstetrics and Gynecology's outpatients, as a control group, is rare (4 of 39 respondents; $10.3 \%$ ) and most of them did their sexual debut at the age of $>18$ years $(89.7 \%)$. The chi-square test showed there was a correlation between the age of coitarche and cervical cancer $(P=.002 ; \mathrm{OR}=6.76 ; 95 \% \mathrm{Cl}$ 2.01-22.75).

Conclusions: Early coitarche has a potential effect on cervical cancer.

\section{INTRODUCTION}

Cancer is a leading cause of woman mortality in the world. Women contribute $49.5 \%$ of the world population, which forms a larger proportion of the population over 60 years [1]. One of the cancers that cause the death of women is cervical cancer (CC). It is the second most common type of cancer suffered by women after breast cancer [2]. Without serious attention, this CC will develop by $25 \%$ for ten years to go [3].

Around 569,847 new cases of CC were recorded and more than half of women worldwide die every year due to CC [4]. This threat develops by the presence of HPV infection. The peak prevalence of oncogenic HPV is infecting the cervix when they get first sexual debuts with a new partner in their adolescence (<18 years) [5], whereas the median age of CC diagnosis is two decades later. Women who have early sexual intercourse in their adolescence ( $<18$ years) are 3 times more likely to get CC because, in this age group, cervical mucous cells are immature and will be more sensitive to get changes that can turn into abnormal conditions $[6,7,8]$.

The researcher approximated about $40 \%$ of CC can be prevented by pressing some risk factors that increase CC such as; infectious agents, early coitus, coitus multipartner, sexually transmitted disease, depressing the immune, and lower socio-economy [4,8-10]. Therefore, women's awareness and prevention programs must be increased to prevent those factors $[11,12]$.

Indonesia has started programs to decrease the incidence of CC. One of the government agencies from the Ministry of Health Indonesia; National Population 
and Family Planning Board (BKKBN), has established this program since 2010 called Age Marriage Maturation (PUP). This program aims to put off the pregnancy in $<20$ years old, which will prevent an early coitarche indirectly [14].

The lower education causes limited access to accurate information. Another reason is the lack of awareness of early detection. As a result, most cases were found to have been in the advanced stage and caused death [9]. This study aims to analyze the relationship between the age of coitarche and the incidence of CC in Dr. Soetomo Hospital Surabaya.

\section{METHODS}

\section{Study Design and Participant}

This study used a case-control design. The population in this study was divided into case and control populations, as well as the samples. The case population was all of the outpatients of One-Stop Oncology Polyclinic (POSA) in Dr. Soetomo Hospital while the control population was all of the outpatients of Obstetrics and Gynecology in Dr. Soetomo Hospital. The POSA's outpatients had been diagnosed with CC from biopsy results, determined as sample cases, while the controls were Obstetric and Gynecology outpatients of Dr. Soetomo Hospital who had normal results of cervical cytology by Papanicolaou screening. The inclusive criterion in this study is all of the outpatients who ever had sexual intercourse. Consecutive sampling was applied and a sample size of 39 respondents $(n=78)$ for both case and control groups was obtained by the Lemeshow formula. This research was under the Ethics Committee in Health Research of Dr. Soetomo General Hospital Surabaya with the registration number 0846/KEPK/XII/2018.

In this study, there are potential confounding variables that might be accompanying, such as sexually transmitted disease, multiple male sexual partners, and long-term use of oral contraceptive pills. The author has an interest in the age of coitarche because this factor is a greater risk of CC because of its vulnerability to HPV infection which causes CC. The exposure variable is human papillomavirus (HPV) infection because the first cervical infection with HPV often occurs soon after the first sexual intercourse. Besides that, the bias data could not be overridden; this can happen while patients forget during the interview and there is an error in examination results (false negative or false positive).

\section{Statistical Analysis}

The data were collected in January 2019. The data collection was performed by the guided interview with each respondent in both case and control groups. The interview was conducted by referring to the standard questionnaire with closed questions. The data collected were coded and entered into SPSS (Statistical Package for Social Sciences) version 20. The descriptive data such as frequencies and percentages were used for measurement. The chi-square test was used in data analysis $(\alpha<0.05)$.

\section{RESULTS}

Table 1. Patient's characteristics

\begin{tabular}{|c|c|c|c|c|}
\hline \multirow{2}{*}{ Characteristics } & \multicolumn{2}{|c|}{$\begin{array}{c}\text { Cervical cancer } \\
(n=39)\end{array}$} & \multicolumn{2}{|c|}{$\begin{array}{c}\text { Non-cervical } \\
\text { cancer }(n=39)\end{array}$} \\
\hline & Frequency & $\%$ & Frequency & $\%$ \\
\hline \multicolumn{5}{|l|}{ Age (years old) } \\
\hline 20-30 & 1 & 2.6 & 2 & 5.1 \\
\hline $31-40$ & 2 & 5.1 & 16 & 41 \\
\hline $41-50$ & 9 & 23.1 & 9 & 23.1 \\
\hline $51-60$ & 23 & 59 & 8 & 20.5 \\
\hline $61-70$ & 4 & 10.3 & 2 & 5.1 \\
\hline$>70$ & 0 & 0 & 2 & 5.1 \\
\hline \multicolumn{5}{|c|}{ Educational background } \\
\hline Uneducated & 7 & 18 & 2 & 5.1 \\
\hline $\begin{array}{l}\text { Primary school } \\
\text { (9 years) }\end{array}$ & 27 & 69.2 & 9 & 23.1 \\
\hline High school & 5 & 12.8 & 18 & 46.2 \\
\hline Bachelor degree & 0 & 0 & 10 & 25.6 \\
\hline \multicolumn{5}{|l|}{$\begin{array}{l}\text { Monthly income } \\
\text { More than } \\
\text { minimum wage }\end{array}$} \\
\hline - IDR 3.8 million & 2 & 5.1 & 22 & 56.4 \\
\hline $\begin{array}{l}\text { Less than } \\
\text { minimum wage }\end{array}$ & 37 & 94.9 & 17 & 43.6 \\
\hline \multicolumn{5}{|l|}{ Flour Albus } \\
\hline Yes & 21 & 53.8 & 2 & 5.1 \\
\hline No & 18 & 46.2 & 37 & 94.9 \\
\hline \multicolumn{5}{|c|}{ History of Papanicolaou screening (during 2017) } \\
\hline Yes & 5 & 12.8 & 18 & 46.2 \\
\hline No & 34 & 87.2 & 21 & 53.8 \\
\hline \multicolumn{5}{|c|}{ History of cancer in the family } \\
\hline Yes & 1 & 2.6 & 5 & 12.8 \\
\hline No & 38 & 97.4 & 34 & 87.2 \\
\hline \multicolumn{5}{|l|}{ Age of coitarche } \\
\hline$<18$ years & 17 & 43.6 & 4 & 10.3 \\
\hline$\geq 18$ years & 22 & 56.4 & 35 & 89.7 \\
\hline
\end{tabular}

During the study period, there were 39 respondents $(n=78)$ divided by ratio 1:1 for case and control groups. Most of the CC patients were at the age group of 51-60 years, but non-CC patients as the control group were mostly at the age of $31-40$ years. This result showed that the majority of female cancers are suffered by older adult women (59\%).

The data on the educational background of between CC and non-CC patients are imbalanced. Most CC patients are only elementary school graduates while the non-CC patients had completed their high schools even to the bachelor's degree. These results influence their income. The majority of CC patients get income 
less than minimum wage, while the non-CC patients have quite the same income as the minimum wage, even more. Table 1 shows the characteristics of the respondent patients of each group in detail.
The majority of CC patients had been diagnosed in stage IIIB (64.1\%), which is classified as an advanced stage of cervical cancer. Cervical cancer is mostly suffered by women in $51-60$ years of age (59\%).

Table 2. Association between the age of coitarche and cervical cancer

\begin{tabular}{|c|c|c|c|c|c|c|c|c|c|}
\hline \multirow{2}{*}{ Age of coitarche } & \multicolumn{4}{|c|}{ Cervical Cancer } & \multicolumn{2}{|c|}{ Total } & \multirow{2}{*}{$\mathrm{p}$} & \multirow{2}{*}{ OR } & \multirow{2}{*}{$95 \% \mathrm{Cl}$} \\
\hline & Yes & $\%$ & No & $\%$ & $\mathrm{n}$ & $\%$ & & & \\
\hline$<18$ years & 17 & 43.6 & 4 & 10.3 & 21 & 27 & & & \\
\hline$\geq 18$ years & 22 & 56. & 35 & 89.7 & 57 & 73 & 0.002 & 6.8 & $2.0-22.7$ \\
\hline Total & 39 & 100 & 39 & 100 & 78 & 100 & & & \\
\hline
\end{tabular}

CC: contingency coefficient; OR: odds ratio; $\mathrm{Cl}$ : confidence interval

Table 2 shows that there is a poor correlation between the age of coitarche and CC $(P=.002 ; \mathrm{OR}=6.76$; $\mathrm{CC}=0.352$; $95 \% \mathrm{Cl} 2.01-22.75)$. The OR shows that women who had their first sexual intercourse before 18 years old were 6.761 times higher than those who did after 18 years old.

\section{DISCUSSION}

The age of coitarche is the greatest risk of CC. The debut of sexual activities, particularly among adolescents ( $<18$ years), is associated because of vulnerability to HPV infection [15]. Sexual debut before 18 is a strong determinant of $\mathrm{CC}$ worldwide. The first cervical infection with human papillomavirus (HPV) often occurs soon after the first sexual intercourse, so early age at the first sexual intercourse is a reasonable proxy for early age at the first exposure to HPV [16].

In 2012, 528,000 new cases of CC were recorded. Of 266,000 women who die each year, almost $90 \%$ come from developing countries with medium income, such as South Asia, Southeast Asia, Central America, and East Africa [3]. This can be interpreted that every 2 minutes, there is 1 woman who dies of CC in the world. Without serious attention, CC will develop by $25 \%$ in the next 10 years [11].

In Indonesia, according to the estimates of the Indonesian Ministry of Health, the incidence of CC continues to increase every year by 40,000 cases or $90-100$ new cases per 100,000 each day, and more than 7000 cases of which end in death. Almost $70 \%$ of newly-discovered cases are already in an advanced stage [11].

Based on this study results, most CC patients were diagnosed in stage IIIB (64.1\%), including the advanced stage. Most of these cases happen on the age between 51 and 60 years, in which there is a decrease in women's immune that influences the performance of organ functions [18]. This immune is very important to destroy cancer cells and to retard its growth and spread [9]. Table 1 indicates that CC patients are mostly just elementary school graduates $(46.2 \%)$; moreover, there are uneducated women (17.9\%). This could impact their knowledge about the importance of health and also their income per month for their welfare.

It is different from the control group that has a better education. $46.2 \%$ are high-school graduates, $25.6 \%$ of whom had completed their bachelor's degree. They have a better life because they have more knowledge of screening some diseases. Table 1 also shows that nonCC patients have a better educational background indicated by no vaginal discharge (fluor albus) and earn more than minimum wage per month indicated by routine medical checkup (screening of cervical cancer with Papanicolaou tests). The lower socioeconomic status contributes to the women in getting the best health services [9]. The relationship between sexual debut, fertility, and educational status is bidirectional [26].

The result of this study shows that CC patients who do not perform the Papanicolaou test before have not known the importance and benefit of that test [20]. Another study stated that young women did not get this test because of the lack of knowledge about the availability of screening and their culture [21]. Awareness campaigns should be intensified through hospital visits, mess media and public lectures [22]. From this study, the results show that $87.2 \%$ of CC patients never had early detection with Papanicolaou screening before. The data collection of the history of Papanicolaou screening for the control group is limited to the most recent year, 2017, whereas, for the case group is not limited by year because most POSA's outpatients had been diagnosed a few years back (The history of Papanicolaou screening was asked during the reproductive period in their lifetime).

In this study context, first sexual debut, as well as the age of coitarche, means the women's first time of sexual debut or intercourse that involves the insertion 
of the penis to the vagina. In terms of age, the women's first sexual debut ideally is at the age of 18 years and over because the mucous cells in her genital organ are not susceptible which can turn to abnormal conditions or commonly called cancer [7].

The age of under 18 years is the age of an adolescent girl, not a woman. Poor sexual activities could impact to early marriage or bad sexual experience. The adolescents with early coitarche could have extreme sexual activities such as anal sex and oral sex, which can affect to sexually transmitted diseases (STD). Anal sex without a barrier can increase the risk of HIV five until twenty times compared to vaginal sex [23]. On another side, Nigeria Demographic and Health Survey suggests a considerably strong relationship between early sexual debut and a lifetime experience of having multiple sexual partners, which can increase STD too [16]. Early marriage among poor girls with low education and living in rural areas is evidenced in Asian regions, especially Indonesia [26].

There were 39 respondents diagnosed with CC indicated by positive biopsy results. This study does not show a quite percentage between early coitarche ( $<18$ years) and late coitarche ( $>18$ years) $(43.6 \%$ and $56.4 \%$, respectively) even though the chi-square analysis shows that there is a poor correlation between age of coitarche and CC ( $P=.002)$. This explains that mucous cells on women's late coitarche ( $>18$ years) are not perfectly mature and their immune not in the best condition. Even though the womb has worked functionally since menstruation (9-15 years), but generally, it has completed at the age of 20 years, wherein women consciously get ready for sexual intercourse [24]. The result of this study is strengthened by the contingency coefficient value $(C C=0.3)$. It means that the closeness of correlation between the age of coitarche and CC is poor.

The first sexual activity is suggested at the age of 18 years and above. Women who had experienced the first intercourse at this age are expected to have mature reproductive organs and the mucous cells around the cervix are not influenced by stimulation of sperm cells. The male genital and its chemicals can affect to abnormal cell development if the mucous cell is not ready to receive the stimulation [7].

However, women who experience the first intercourse under 18 years old will have injuries or scratches around the cervix due to the intercourse. The stimulation of the male genital and its content can cause these scratches to invite the cancer-causing virus. If the cervix continues to be exposed to these sperm cells, the cervix will be more susceptible to the carcinogen stimulation because there is an active squamous metaplasia process that can cause CC [7].

Most of the patients in the control group did their sexual debut at the age of 18 years above (89.7\%). It is approximated that mucous cells and reproductive organs are not mature and ready to receive external stimulation (7). This is supported by the preventive activity which identifies the development of abnormal cells caused by human papillomavirus (HPV). The golden standard to identify is by using Papanicolaou screening (Table 1). It does not rule out the possibility that women with normal results would experience CC in the future because the rapid development of precancer to invasive carcinoma is rare. It generally takes 10 to 15 years [25]. Further studies need to be conducted to prove this argument.

The diagnosis of CC is determined not only by one factor, age of coitarche, but also by many other contributors associated with the occurrence of CC such as parity, age at first labor, oral contraceptive use, and multiple sexual partners. This becomes the limitation of this study.

\section{CONCLUSIONS}

It can be concluded that there is a significant correlation based on the bivariate analysis between the age of coitarche and the incidence of cervical cancer. The earlier the age of a woman in having sexual intercourse (coitarche) is, the higher the incidence of cervical cancer will occur. A woman with an early coitarche ( $<18$ years) could increase the chance of cervical cancer by 6.761 times.

\section{DECLARATIONS}

\section{Competing of Interest}

I declare that I do not have any competing interests.

\section{Acknowledgement}

I wish to thank all of the sides who contribute to this research until it was done.

\section{REFERENCES}

1. Torre LA, Islami F, Siegel RL, Ward EM, Jemal A. Global cancer in women: Burden and trends. Cancer Epidemiol Biomarkers Prev. 2017;26(4):444-57.

2. Vaccarella S, Laversanne M, Ferlay J, Bray F. Cervical cancer in Africa, Latin America and the Caribbean and Asia: Regional inequalities and changing trends. Int J Cancer. 2017;141:1997-2001.

3. World Health Organization. Comprehensive cervical cancer control: a guide to essential practice-2nd ed. WHO Press. 2014. 
4. Bray F, Ferlay J, Soerjomataram I, Siegel RL, Torre LA, Jemal A. Global cancer statistics 2018: GLOBOCAN estimates of incidence and mortality worldwide for 36 cancers in 185 countries. Ca Cancer J Clin. 2018;68:394-424.

5. Castellsagué $X$, Paavonen J, Jaisamrarn U, Wheeler CM, Skinner SR, et al. Risk of first cervical HPV infection and pre-cancerous lesions after onset of sexual activity: analysis of women in the control arm of the randomized, controlled PATRICIA trial. BMC Infect Dis. 2014;14(551):1-12.

6. Lubis R, Siregar F, Sanusi S. Pengaruh usia pertama kali melakukan hubungan seksual, paritas, bergantiganti pasangan seksual, merokok terhadap kejadian Kanker Serviks di RSUD Dr. Pirngadi Medan. Jurnal Muara Sains, Teknologi, Kedokteran, dan IImu Kesehatan. 2017;1(2):145-52.

7. Diananda R. Panduan lengkap mengenal Kanker. Mirza Media Pustaka. 2009.

8. Rasjidi I. Epidemiologi kanker pada wanita. Sagung Seto. 2010.

9. Ariani S. Stop kanker. Istana Media. 2015.

10. Indrawati M. Bahaya kanker bagi wanita dan pria. AV Publisher. 2009.

11. Kementerian Kesehatan RI. Panduan program nasional gerakan pencegahan dan deteksi dini kanker leher Rahim dan kanker payudara. Direktorat PP dan PTM. 2015.

12. Liu G, Sharma M, Tan N, Barnabas R. HIV-positive women have higher risk of HPV infection, precancerous lesions, and cervical cancer: A systematic review and meta-analysis. HHS Public Access. 2018;32(6):795-808.

13. Makkonen $P$, Heinävaara $S$, Sarkeala $T$, Anttila $A$. Impact of organized and opportunistic Pap testing on the risk of cervical cancer in young women - A case-control study from Finland. Gynecol Oncol. 2017;147(3):601-6.

14. Natalia IW. Strategi komunikasi perwakilan BKKBN Provinsi Jawa Timur dalam mensosialisasikan pemahaman pendewasaan usia perkawinan (PUP) kepada remaja menuju keluarga kecil bahagia sejahtera. Jejaring Administrasi Publik. 2016;8(1):847-66.

15. Gloria AC, Oyine AD, Henrietta OU. Knowledge, attitudes, and practice of cervical cancer prevention among student health professionals in Nigeria. Asian Pac J Cancer Care. 2019;4(4):125-30.

16. Plummer M, Peto J, Franceschi S. Cancer on behalf of the IC of ES of C. Time since first sexual intercourse and the risk of cervical cancer. Int J Cancer. 2012; 120(11):2638-44.

17. Rizzo AE, Feldman S. Update on primary HPV screening for cervical cancer prevention. Curr Probl Cancer. 2018;42(5):507-20.

18. Latham-Cork H, Porter C, Straw F. Sexual health in young people. J Paediatr Child Health. 2018;28(2):93-9.

19. Yaya S, Bishwajit G. Age at first sexual intercourse and multiple sexual partnerships among women in Nigeria: A cross-sectional analysis. Front Med. 2018;5(171):1-8.

20. Tapera R, Manyala E, Erick P, Maswabi TM, Tumoyagae $T$, et al. Knowledge and attitudes towards cervical cancer screening amongst University of Botswana female students. Asian Pac J Cancer Prev. 2017;18(9):2445-50.

21. Blödt S, Holmberg C, Müller-Nordhorn J, Rieckmann N. Human papillomavirus awareness, knowledge and vaccine acceptance: A survey among 18-25 year old male and female vocational school students in Berlin, Germany. Eur J Pub Health. 2012;22(6):808-13.

22. Okore $\mathrm{O}$. The use of health promotion to increase the uptake of cervical cancer screening program in Nyangabgwe Hospital, Botswana. University of Limpopo (medunsa Campus). 2011.

23. Gordon LP, Diaz A, Soghomonian C, Nucci-Sack AT, Weiss JM, et al. Increased body mass index associated with increased risky sexual behaviors. J Pediatr Adollesc Gynecol. 2017;29(1):42-7.

24. Bertiani ES. Cara cerdas menghadapi Kanker serviks. Genius Publisher. 2009.

25. Carcio HA, Secor M. Advanced health assessment of women, fouth edition: clinical skills and procedures. Springer Publishing Company. 2018.

26. Montazeri S, Gharacheh $\mathrm{M}$, Mohammadi N, Alaghband RJ, Eftekhar AH. Determinants of early marriage from married girls' perspectives in Iranian setting: a qualitative study. J Environ Public Health. 2016;2016:1-8. 